\title{
Insulin, aging, and the brain: mechanisms and implications
}

\author{
Abimbola A. Akintola* and Diana van Heemst \\ Department of Gerontology and Geriatrics, Leiden University Medical Center, Leiden, Netherlands
}

\section{Edited by:}

Hubert Vaudry, University of Rouen,

France

Reviewed by:

Catarina Oliveira, University of Coimbra, Portugal

Andrzej Bartke, Southern Illinois

University School of Medicine, USA

${ }^{*}$ Correspondence:

Abimbola A. Akintola, Department of

Gerontology and Geriatrics, Leiden

University Medical Center, C7-124,

Albinusdreef 2, Leiden 2333 ZA,

Netherlands

e-mail:a.a.akintola@lumc.nl
There is now an impressive body of literature implicating insulin and insulin signaling in successful aging and longevity. New information from in vivo and in vitro studies concerning insulin and insulin receptors has extended our understanding of the physiological role of insulin in the brain. However, the relevance of these to aging and longevity remains to be elucidated. Here, we review advances in our understanding of the physiological role of insulin in the brain, how insulin gets into the brain, and its relevance to aging and longevity. Furthermore, we examine possible future therapeutic applications and implications of insulin in the context of available models of delayed and accelerated aging.

Keywords: insulin, insulin receptors, brain, inflammation, delayed aging, accelerated aging, longevity

\section{INTRODUCTION}

Pathways that orchestrate the responses of the organism to changes in its environment have been implicated in the genetic regulation of lifespan across different species. One of the key pathways identified by genetic analysis of long-lived Caenorhabditis elegans ( $C$. elegans) mutants is insulin/insulin-like growth factor-1 (IGF-1) signaling (IIS) $(1,2)$. In invertebrates, multiple insulin/IGF-1-like ligands signal via a common receptor, which shows homology to the mammalian insulin and IGF-1 receptors. Also in mammals, insulin/IGF-1 signaling has been linked to aging, lifespan, and longevity (3). Although in mammals, insulin and IGF-1 act predominantly via distinct receptors, there is extensive overlap and interaction in their downstream signaling cascades, making it difficult to separate effects of insulin signaling from those of IGF-1 signaling. The long-lived phenotype of FIRKO mice, which were made by selective disruption of the insulin receptor (IR) in adipose tissue, supports a role of insulin signaling in longevity (4). Moreover, many of the long-lived mouse mutants with disrupted GH/IGF-1 signaling display enhanced insulin sensitivity. In humans, a hallmark phenotype of healthy longevity is maintenance of insulin sensitivity $(5,6)$, which has been observed in familial human longevity $(7,8)$, as well as in centenarians (9-11). Insulin influences all aspects of human physiology (12, 13). Besides regulating peripheral glucose homeostasis, insulin is an important neuromodulator that contributes to neurobiological processes (14), with growing evidence that insulin supports behavioral, cellular, biochemical, and molecular functions (15). In literature, evidence linking aging and insulin signaling includes prolongation of life span in rodents via genetic mutations affecting insulin signaling pathways or via interventions that down-regulate nutrient sensing pathways such as caloric restriction. Further evidence includes data on the role of type 2 diabetes in accelerated aging syndromes, and the increased incidence of insulin resistance with age (16). In model organisms (nematodes and fruit flies), specific neural manipulations of insulin signaling have also been linked to aging and lifespan $(17,18)$. Insulin is produced in the brain of these organisms, making it undoubtedly a neuropeptide. In mammals and humans, IRs are highly abundant in many brain areas and nuclei, but it remains unclear if insulin is produced in the brain. Furthermore, the physiological and pathophysiological mechanisms of insulin action in the brain in relation to aging and longevity remain to be elucidated.

With the global population aging, there has been an astonishing increase in the prevalence of obesity (19), metabolic syndrome (20), type 2 diabetes (21), and neurodegenerative diseases (22). Insulin resistance is a shared feature in these diverse pathologies $(13,23-26)$. It therefore becomes critical to understand the role of insulin in healthy longevity, as this may be relevant to combatting age-related disorders that have been linked to disturbances in glucose metabolism. The aim of this article is to review advances in our knowledge about insulin, insulin signaling, and the brain, and to present these in the context of available models of delayed and accelerated aging. Furthermore, we will examine the links between inflammation, metabolic health, and brain health, and their effect on aging. Finally, we will review therapeutic options to enhance brain insulin action, including measures to enhance local brain insulin levels as well as measures to enhance the brain responses to insulin.

\section{INSULIN AND THE BRAIN: A CENTURY OF DISCOVERIES}

Insulin, after discovery in 1921 , was initially considered a peripheral hormone and thus unable to cross the blood-brain barrier (BBB) (27). However, in 1967, Margolis and Altszuler demonstrated in dogs that the concentration of cerebrospinal fluid (CSF) insulin increased after an increase in plasma insulin (28), thus showing that insulin is able to cross the blood-CSF barrier. In 1978, Havrankova et al. demonstrated the widespread presence of IRs in the central nervous system (CNS) of the rat (29). Later that year, they further demonstrated that high levels of insulin were present in rat brain extracts, and found that the concentration of insulin in the CNS was considerably higher than its concentration in the circulation (30). They thus proposed a physiological role 
for insulin in the CNS. In the 1980s, further evidence that insulin from peripheral circulation crosses the BBB thus gaining access to the brain was provided. In 1983, Dorn et al. demonstrated that the human brain contains insulin in concentrations much higher than the blood, the highest being in the hypothalamus (31). Furthermore, they showed the presence of high concentrations of insulin in the brains and spinal cords of human cadavers, mice, and rats (32). Baskin et al. demonstrated uptake in the hypothalamus of [125I]iodoinsulin after the insulin had been stereotaxically injected into a lateral cerebral ventricle. Furthermore, they detected insulin-like immunoreactivity in the periventricular, supraoptic, suprachiasmatic, arcuate, and lateral hypothalamic nuclei of the rat hypothalamus $(33,34)$. In 1992, Schechter et al. delineated the ontogeny of rabbit brain insulin concentration and demonstrated that insulin availability is developmentally regulated (35). In the past decade, studies of the effects of insulin in the brain have been enhanced after development of non-invasive methods of selective delivery of insulin into the brain, via the intranasal route, circumventing peripheral effects of systemic hypoglycemia (36). This has advanced our understanding of potentially therapeutic effects of enhancing insulin concentrations in the brain. Furthermore, studies in recent years have brought forward the role of insulin signaling in the hypothalamus, as a key player in regulation of hepatic glucose production and food intake (37).

\section{BRAIN INSULIN: IS INSULIN A NEUROPEPTIDE IN HUMANS?}

In the rabbit, discordance was observed between insulin concentrations in serum and CSF (35). Insulin was found to be present in high concentrations in brain micro-vessels (38), brain extracts (39), and immature nerve cell bodies (35, 40), despite that only $0.046 \%$ of peripheral insulin crosses the BBB in mice $(12,41)$. Moreover, brain insulin concentrations were observed to vary according to developmental stages, with peak amounts being observed during the critical phases of brain growth and development (42). Taken together, these results suggest that brain insulin availability is strictly regulated and can reach high levels in the CNS. This raises the question as to the source of brain insulin, does all of brain insulin derive from the periphery or is insulin also synthesized in the brain (Figure 1)?

There is unequivocal evidence for selective, regulated, time dependent, temperature sensitive, carrier mediated, and saturable insulin transport to the brain (43-50). In mice, human insulin was shown to access the CNS after crossing the BBB (51). In rabbits, insulin infused into the carotid artery was shown to have crossed the BBB into the peri-capillary space and brain parenchyma with preservation of the peptide's integrity (45). In dogs, studies using a three component mathematical model (plasma, intermediate component, and CSF) have shown that insulin delivery to the CNS fits a receptor-mediated saturable process (43). In healthy humans, during hyperinsulinemic, euglycemic clamp studies, increase in circulating insulin was demonstrated to rapidly affect brain activity, alongside rapid cerebral insulin signal transduction, independent of the systemic effects of the insulin (48).

Apart from passage through the $\mathrm{BBB}$, direct access of insulin to the CSF has also been demonstrated (Figure 1). This alternative

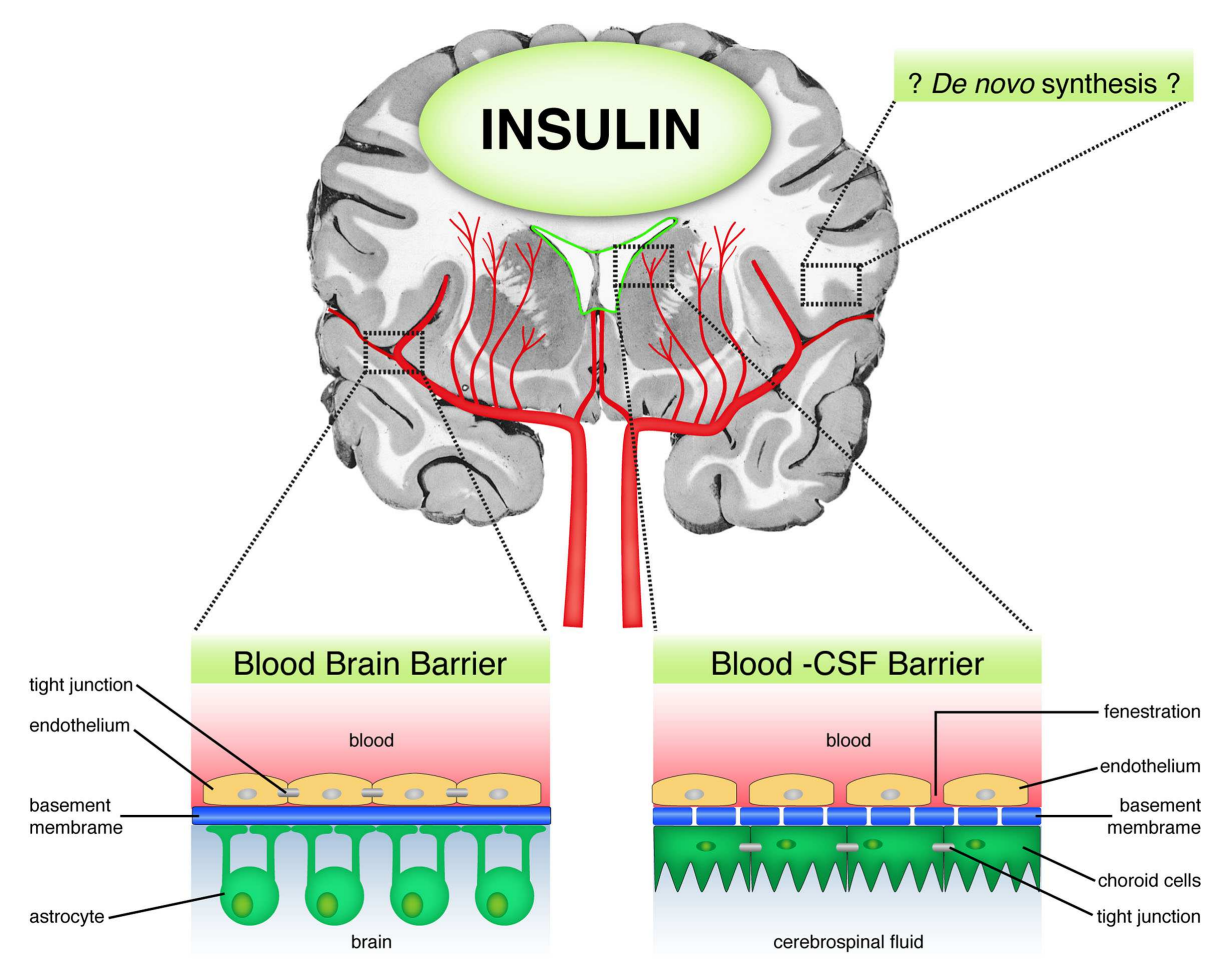

FIGURE 1 | Sources of brain insulin. Schematic diagram showing the possible sources of brain insulin. First, peripheral insulin can access the brain through the blood brain barrier (BBB) via a selective, carrier-mediated transport system. Second, insulin may diffuse through the blood-CSF barrier in circumventricular regions, which are lacking in BBB. Third, there is some limited evidence suggesting the possibility of de novo insulin synthesis in the brain. 
route occurs through circumventricular regions, such as the area postrema, which lack a BBB $(34,52-54)$. Unlike the BBB that contains tight junctions, the capillaries in the circumventricular regions are porous, thereby allowing plasma solubles to diffuse freely and directly into these areas (55). The route through which insulin accesses the brain has implications for the rate of convection and diffusion in the brain, and distribution of the insulin into the brain parenchyma. Following intraventricular administration of insulin, insulin becomes distributed through the ventricular compartments and to the surface of the brain bathed by the subarachnoid space, with relatively slow rate of diffusion into the brain parenchyma, and is minimal at distances more than $1-2 \mathrm{~mm}$ removed from the CSF surface $(55,56)$. In addition, insulin delivered into the CSF undergoes relatively rapid bulk flow through the CSF flow tracks. For example, the entire CSF volume is turned over every $4-5 \mathrm{~h}$ following production at the choroid plexus in the human brain (55).

In model organisms, insulin is biosynthesized by neurons in the brain and it exerts both local and remote actions, including regulation of homeostasis; making it undoubtedly a neuropeptide. In humans, however, insulin is mainly produced in the pancreas, which raises the question as to whether insulin can be considered a neuropeptide in humans. Neuropeptides have been defined as "small proteinaceous substances produced and released by neurons through the regulated secretory route and acting on neural substrates" (57). Neuropeptides have been shown to have strict, cell specific expression patterns, on which the physiological or behavioral role of the peptides is based. Criteria for classification as a neuropeptide include gene expression and biosynthesis by neurons; storage, and regulated release upon demand and ability to modulate or mediate neural functioning directly through receptors (57). Although IRs are highly abundant in many brain areas and nuclei, it remains unclear if insulin is produced in the brain. Therefore, following the strict criteria for neuropeptide definition, it becomes debatable if mammalian insulin is a true neuropeptide.

Evidence in favor of insulin synthesis in the brain mostly derives from in vitro studies, including the study by Clarke et al. in 1986, which demonstrated the synthesis of insulin by cultured rat brain neuronal and astrocyte glial cells and their release of insulin in primary culture. The insulin release after membrane depolarization of the neurons was biphasic, in a manner similar to that of pancreatic beta cells (58). In 1990s, Schechter et al. provided both in vivo and in vitro evidence from mammalian brains supporting the de novo synthesis of insulin. In vitro evidence included the demonstration of preproinsulin I and II mRNA in neuron cell cultures of fetal rat brains (59). From in vivo studies, presence of preproinsulin I and II mRNAs and insulin immunoreaction was detected within the rough endoplasmic reticulum, the Golgi apparatus, cytoplasm, axon, synapsis, and dendrites of the rat fetal brain (40).

Summarily, as can be seen in Figure 1, whether insulin is derived from the periphery, local sources or both, insulin is present in the CNS, where it subserves many functions and contributes to neurobiological processes.

\section{ACTIVATION OF INSULIN RECEPTORS IN THE BRAIN}

As in peripheral tissues, insulin signaling in the brain occurs mainly via the IR pathway (Figure 2 ), which contains several

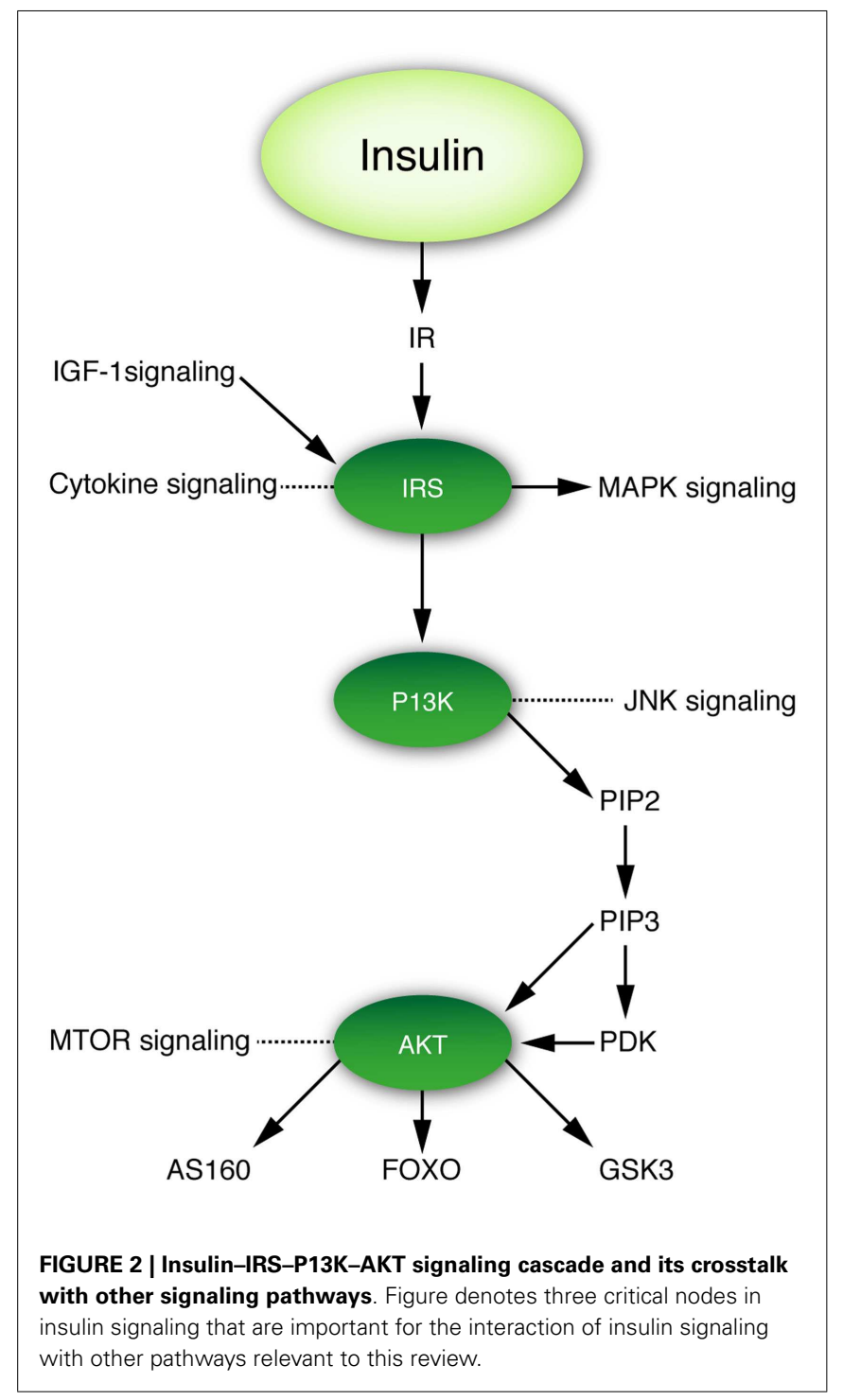

critical nodes of interaction with other signaling pathways (60). Activation of the insulin signaling cascade starts with binding of the insulin ligand to the IR, which belongs to the family of tyrosine kinase receptors, auto phosphorylation of which is essential for their activation. Upon activation, the IR phosphorylates insulin receptor substrate (IRS) proteins. IRS proteins are also activated upon binding of the IGF-1 ligand to its cognate receptor. Thus, IRS proteins represent a critical node of conversion of the insulin and IGF-1 signaling cascades, and their crosstalk with other pathways, such as cytokine signaling. In addition to its activation of the Ras-mitogen-activated protein kinase (MAPK) pathway, activated IRS proteins serve as docking sites for the assembly and activation of, among others, phospho-inositol-3 kinase (PI3K), which generates the lipid second messenger phosphatidylinositol 3,4,5-triphosphate (PIP3). PI3K represents another critical node of crosstalk with other signaling pathways, including the c-Jun-Nterminal kinase (JNK) stress signaling pathway. Elevated levels of PIP3 activate phosphoinositide-dependent protein kinase-1 
(PDK1) and AKT. AKT represents yet another critical node of interaction with the mammalian target of rapamycin (mTOR) nutrient signaling pathway. AKT targets include glycogen synthase kinase 3 (GSK3), Akt substrate of $160 \mathrm{kDa}$ (AS160, phosphorylation of which is required for translocation of the glucose transporter GLUT4 to the plasma membrane) and forkhead transcription factors (FOXOs) (Figure 2). Phosphorylation of FOXOs induces their translocation from the nucleus, which causes profound changes in the transcription of key factors implicated in metabolism, cell cycle regulation, apoptosis, and resistance to oxidative stress (61).

\section{DISTRIBUTION OF INSULIN RECEPTORS IN THE BRAIN}

In higher mammals and humans, IRs are widely distributed throughout peripheral tissues, with their main function being to transport glucose into cells, inhibit glucose production and increase glucose uptake by triggering signaling pathways in the liver, muscle, and fat (62). The IR consists of a tetramer, with two alpha subunits and two beta subunits. Brain IR subunits differ structurally from peripheral IR subunits in that they have a lower molecular weight (63) and can withstand exposure to high concentrations of insulin without undergoing down-regulation (64, 65). The mammalian brain has specific IRs $(29,66)$, which are of two types. One is the neuronal/neuron-specific type, which is abundant in the neuron (67), while the second type is the nonneuronal/peripheral-like type, with lower density in glial cells $(38,66,68)$. Insulin receptors are highly abundant in the neurons, with high protein concentrations in cell bodies and synapses, and less abundant in the glia. Brain IRs are abundant in the brain, but are highly enriched in the olfactory bulb, hypothalamus, hippocampus, cerebellum, amygdala, and cerebral cortex (12).

Growing but controversial evidence suggests that the specific regional concentrations of IR reflect different IR functions associated with particular brain regions. IR enrichment in the hypothalamus and limbic system including the hippocampus, pyriform cortex, and amygdala, areas that reciprocally connect and communicate with each other, has been proposed to be suggestive of a role in emotion and higher cognitive functions, particularly learning and memory $(69,70)$. Higher IR concentrations are found in the hippocampus, which is critically involved in spatial memory processing, suggesting insulin's role in learning and declarative memory (69). Evidence that synthesis of IR may be increased in these hippocampal areas as a result of learning is supported by the up-regulation and the changes in distribution patterns of IR mRNA in the hippocampus and dentate gyrus following water maze training in rats (70). Insulin is involved in the regulation of food intake, which is consistent with the high concentrations of IR in the olfactory bulb and the hypothalamus. Furthermore, the high concentration of IR in the choroid plexus suggests that it may be required for transport of peripheral insulin across the blood-CSF barrier (70).

\section{FUNCTIONAL SIGNIFICANCE OF INSULIN IN THE BRAIN}

As the most potent anabolic hormone yet identified, insulin has both metabolic and non-metabolic functions. Insulin regulates food intake, as well as glucose, lipid, and energy homeostasis and stimulates synthesis (as well as inhibition of breakdown) of glycogen, triglycerides, and most proteins. It is also involved in regulation of hedonic behavior and non-homeostatic control of intake of food and other substances via reward processing.

\section{NON-METABOLIC FUNCTIONS}

The presence of insulin and IRs in the brain indicates that the brain is a target organ for insulin. Insulin plays a key role in synaptic plasticity, apoptosis, mood, learning, reproduction, and growth $(37,71-74)$. Insulin and IR expression in the brain has been suggested to exert neurotrophic effects on CNS neurons (75). Insulin has been considered to support neuronal protein synthesis and cytoskeletal protein expression (75), neurite outgrowth $(76,77)$, migration, and differentiation in the absence of other growth factors $(78,79)$, and nascent synapse formation $(75$, 80 ). It promotes growth and regeneration of axonal sprouts, especially small sized sensory neurons (81), neuronal survival, circuit development, synaptic plasticity (82), and postsynaptic neurotransmitter receptor trafficking (80). Evidence in favor of insulin's role as a neurotransmitter in the CNS includes the observations that (i) insulin is present in neurons (67), (ii) neurons contain specific IRs (64), and (iii) insulin affects neuronal firing and catecholamine metabolism (83-85). Insulin also has effects on BBB function, including ability to affect the transport of other substances. Binding sites for insulin have been described at both the choroid plexus and on brain endothelial cells $(86,87)$. Insulin also has neuro-protective properties (88-90). Central insulin plays a role in cognitive processes such as attention, executive functioning, learning, and memory (91), and direct application of insulin to the CNS in humans has been shown to improve memory and cognition $(92,93)$. Thus, insulin is involved in attributes that are essential for healthy aging.

\section{METABOLIC FUNCTIONS}

The brain plays a key role in maintenance of homeostasis, or the ability to maintain vital parameters of the internal environment within narrow limits, despite fluctuations in the external environment. Metabolic homeostasis requires the integration of numerous cues reflecting energy availability by the hypothalamus and nearby brain structures, to mount a coordinated response to adapt fuel flux so as to maintain energy homeostasis. Insulin is one of the many cues informing the brain about energy status. Research on insulin signaling has primarily focused on insulinmediated processes in the classical insulin target organs. These include glucose uptake into skeletal muscle, inhibition of glucose production by the liver, and inhibition of lipolysis in adipose tissue. However, in 1979, a role for insulin in the central regulation of energy homeostasis was suggested based on the observations that insulin levels circulate in proportion to fat mass in most mammals and that intra-cerebroventricular insulin administration results in a dose dependent reduction in food intake and body weight in monkeys (94). In line, IRs are expressed throughout the mammalian brain (29). Metabolic syndrome and diabetes have traditionally been considered as peripheral metabolic diseases. Recently, various non-invasive brain-imaging techniques have revealed structural and functional abnormalities that are associated with diabetes. Critical autonomic regulatory neurons 
in the hypothalamus and brainstem are responsible for maintenance of energy homeostasis and functional changes in these areas are associated with the development of diabetes (95). It was also shown that after hepatic branch vagotomy the suppression of hepatic gluconeogenesis induced by increasing circulating insulin levels was reduced by half (96). Mechanistically, binding of insulin to the IR and activation of the PI3K pathway in hypothalamic glucose-responsive neurons, which was shown to induce their hyperpolarization by opening of ATP-dependent potassium channels (97), has been implicated in the central effects of insulin on hepatic glucose production (96). Recently, it was shown that ingestion of a glucose solution resulted in a prolonged and significant blood oxygen dependent decrease in activity in the hypothalamus of healthy subjects, but not in type 2 diabetic patients (98). Insulin is also involved in regulation of energy homeostasis via IR in the ventromedial hypothalamus and acts on the brain to suppress feeding (99). Thus, insulin acts as a satiety factor, a finding supported by the observation that the response of glucose-excited neurons in the ventrolateral and ventromedial hypothalamic nucleus to decreased glucose is blunted by insulin (100).

Taken together, these data indicate that, beside peripheral insulin resistance, reduced brain insulin action may also contribute to loss of maintenance of metabolic control. Indeed, brain specific deletion of the IR was shown to result in enhanced food intake in female mice; and in mild obesity, hyperleptinemia, insulin resistance, and hypertriglyceridemia in both male and female mice (101). In line with these findings, in rats, decreasing hypothalamic IRs caused overeating and insulin resistance and hypothalamic insulin signaling was shown to be required for inhibition of glucose production (102). High-fat diet-induced obesity is associated with reduced brain insulin transport and an impairment of insulin action when given directly into the CNS, suggesting a loss of the effectiveness of insulin in the CNS to provide feedback signaling in circumstances of chronic hyperinsulinemia (103). Upon aging, peripheral insulin resistance progressively increases, inducing compensatory chronic elevations in circulating insulin levels. Therefore, central insulin action will be discussed in the context of models of delayed and accelerated aging.

\section{INSULIN AND THE BRAIN: MODELS OF DELAYED AGING NEMATODE MODELS OF DELAYED AGING}

There is an impressive body of literature implicating insulin/IGF1 like ligands and insulin/IGF-1 signaling in the regulation of metabolism, development, and longevity in the roundworm $C$. elegans (104). In response to unfavorable stressful environmental conditions, $C$. elegans larvae can transiently exit the cycle of growth and development to sexual maturity by transformation into developmentally arrested, non-feeding, stress resistant, and long-lived dauer larvae $(105,106)$. It was found that several dauer formation defective (daf) mutants are also long-lived, possibly because these mutants display specific key features of the dauer stage while developing in sexually mature adults, such as enhanced resistance to multiple stresses due to induction of cytoprotective pathways (107). Of the many long-lived daf mutants in nematodes, the ones that are best characterized comprise the daf-2, age-1 (daf 23), daf-16, and daf-18 mutants. Cloning and sequencing of the loci affected in long-lived daf mutants has revealed that these show strong sequence homology with evolutionarily conserved components of the mammalian insulin/insulin-like growth factor1 signal transduction cascade (108-110). For example, the daf-2 gene that has been shown to regulate lifespan in C. elegans, and the related tyrosine kinase receptors InR in Drosophila melanogaster (D. melanogaster) encode components that are homologous to the mammalian insulin and insulin-like growth factor-1 receptors. In response to food or the perception of food, multiple insulinlike ligands are secreted from neurosecretory cells in the brain of C. elegans (111) and D. melanogaster (112), indicating that in these invertebrates, the CNS plays a key role in insulin signaling mediated regulation of physiology and lifespan in response to environmental cues. Moreover, more than 10 years ago, Wolkow et al. (17) demonstrated that restoration of the daf- 2 pathway of insulin-like signaling in neurons alone was sufficient to restore wildtype lifespan in C. elegans, and thus provided further evidence as to the role of insulin in the nervous system as a central regulator of animal longevity.

\section{MOUSE MODELS OF DELAYED AGING}

In mammals, the insulin/insulin-like growth factor-1 signaling cascade exhibits some striking differences compared to the insulin/insulin-like growth factor-1 signaling cascade in invertebrates (113). These differences include the acquisition of $\mathrm{GH}$ as a main regulator of IGF-1 production by the liver, and the acquisition of separate receptors for insulin and IGF-1. Again, several of the existing long-lived mammalian mutants with defects in insulin/IGF-1 signaling point to a role of the CNS in the regulation of mammalian longevity. The mutations that have thus far been most consistently and most strongly associated with increases in lifespan in mice comprise the Prop-1 mutation displayed by Ames dwarf mice (114) and the Pit-1 mutation displayed by Snell dwarf mice (115). These two mutations confer a defect in the development of the anterior pituitary gland, which causes a lifelong combined hormonal deficiency in growth hormone, thyroid stimulating hormone, and prolactin. In these as well as other longlived mice, longevity has been strongly correlated with enhanced insulin sensitivity (116). In addition to the Ames and Snell dwarf mice, many other mouse mutants with defects in insulin/IGF-1 signaling have been described to display a longevity phenotype, which strongly implicates the insulin/IGF-1 signaling pathway in the regulation of rodent longevity. Involvement of both insulin signaling and IGF-1 signaling in mouse longevity was suggested by the long-lived phenotypes displayed by mice with selective disruption of the IR in adipose tissue (4) and mice heterozygous for mutation of IGF-1R (1). Summarily, improved insulin control (of carbohydrate homeostasis) has been identified as one of the pathways implicated in the remarkable extension of longevity in long-lived mouse mutants (117).

\section{HUMAN MODELS OF DELAYED AGING}

Also in humans, preserved insulin sensitivity has been associated with longevity. Insulin resistance has been shown to predict the development of age-related diseases, including hypertension, coronary heart disease, stroke, cancer, and type 2 diabetes (118). In the general population, the association between aging and 
decline in insulin sensitivity (119-123) has been demonstrated in several studies (Figure 3). Mechanisms suggested to contribute to decreased insulin sensitivity in the elderly include (i) age-related receptor and post-receptor defects in insulin action $(124,125)$, (ii) an age-related decrease in insulin stimulated whole body glucose oxidation (126), (iii) an age-related reduction in beta cell response to glucose (126), and (iv) impaired insulin-mediated glucose uptake, and inability to suppress hepatic glucose output (127, 128). In contrast, centenarians, which exhibit exceptional longevity, seem protected against the age-related decline in insulin sensitivity when compared to a group of advanced middle-aged individuals. (11) Of note, a methodological difficulty that is associated with the comparison of groups that differ in calendar age is potential confounding by the changes that occur in body composition and endocrine function with advancing age. Moreover, differences may exist between different birth cohorts in environmental impacts, including differences in the availability vaccinations or medications (e.g., antibiotics).

The relationship between longevity and preserved insulin action has also been observed in studies of familial longevity. In the Leiden longevity study, offspring of long-lived nonagenarian siblings, having inherited on average $50 \%$ of the genetic propensity of their long-lived parent were included together with the partners of the offspring (129), with whom they have shared the same socioeconomic and geographical environment for decades and who are of a similar age. We showed that already at middle age the offspring from these long-lived siblings displayed a decreased mortality risk suggesting that there is indeed evidence for genetic enrichment for longevity (129). Moreover, human offspring of exceptionally long-lived siblings, when compared to their partners showed a remarkably lower prevalence of metabolic syndrome (130) and diabetes (131). After exclusion of diabetic patients, the offspring of exceptionally long-lived siblings displayed lower circulating levels of glucose and slightly lower circulating insulin levels (7). Using hyperinsulinemic euglycemic clamps studies, we could show that the offspring of long-lived siblings specifically displayed enhanced peripheral insulin sensitivity compared to age matched controls (8). A study using high field (7-T) MR spectroscopy of the tibialis anterior muscle indicated that the enhanced peripheral insulin sensitivity of offspring is associated with lower intramyocellular lipid content, which may be indicative of better mitochondrial capacity (132).

The mechanisms underlying the preserved insulin action in centenarians as well as in offspring of nonagenarian siblings remain unclear. However, suggested mechanisms include genetic enrichment for favorable features related to body fat and lipoprotein distribution, reduced plasma free radical concentrations, and enhanced cellular response to oxidative stress and immune function $(11,133,134)$. Taken together, these results suggest that maintenance of insulin sensitivity is a key feature of healthy longevity.

\section{INSULIN AND THE BRAIN: MODELS OF ACCELERATED AGING OBESITY AS A MODEL FOR ACCELERATED AGING}

The most common acquired factors causing insulin resistance are obesity and a sedentary lifestyle. Obesity and the associated increase in body fat are the consequences of chronic, long-term nutrient excess. In Western societies, the prevalence of obesity continues to increase and numerous studies have demonstrated an association between obesity and enhanced mortality risk (135). The relationship between obesity and excess mortality is consistent with evidence that obese individuals are at increased risk of essential hypertension, type 2 diabetes mellitus (DM2), and cardiovascular disease (CVD). It has been suggested that insulin

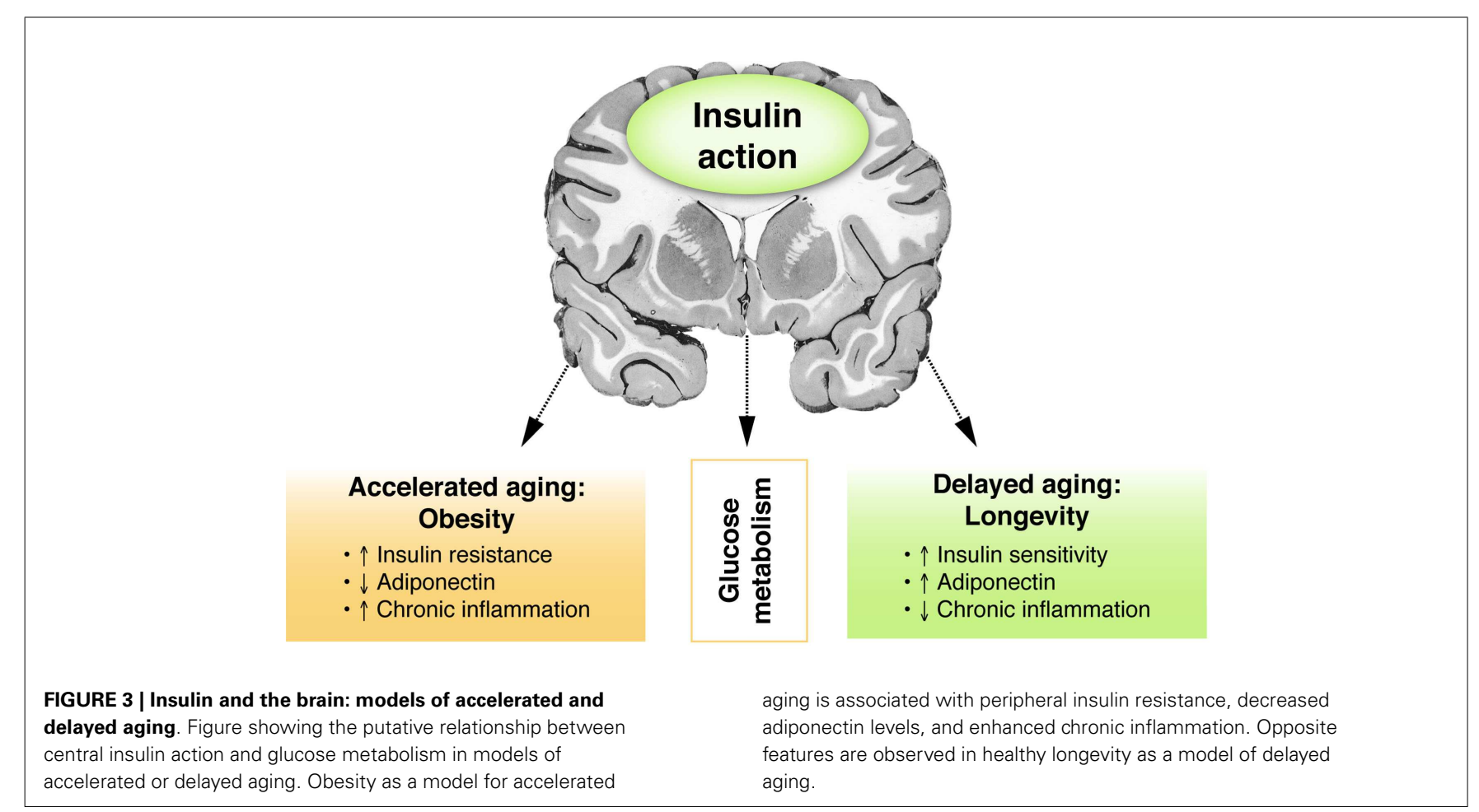


resistance is the major contributor to clinical outcomes associated with obesity (136).

It is not known why some obese individuals develop insulin resistance while others remain insulin sensitive (137). A potential mechanism that might explain the association between excess adiposity and peripheral insulin resistance is impaired adipogenesis and reduced lipogenesis in subcutaneous fat, which would lead to enhanced deposition of fat in the visceral depots and larger sizes of visceral adipocytes $(137,138)$. Increased visceral adiposity is associated with enhanced secretion of inflammatory cytokines and induction of insulin resistance (139). Nutrient excess results in enhanced exposure of cells and tissues to high levels of circulatory glucose and fatty acids. These exposures can activate various intracellular inflammatory pathways and lead to mitochondrial dysfunction, reactive oxygen species (ROS), ER stress, and the associated unfolded protein response that induce resistance to both leptin and insulin (140). ROS can have both stimulatory and inhibitory effects on insulin signaling. It was shown that under normal physiological conditions, optimal activation of the IR requires redox priming by IR mediated activation of $\mathrm{NAD}(\mathrm{P}) \mathrm{H}$ oxidase (NOX) in many cell types (141). In addition, mild bursts in intracellular ROS can activate the IR receptor independent of insulin, allowing for ROS mediated ligand activation bypass of IR signaling (142). In contrast, increased levels of ROS or prolonged exposure to oxidative stress have been shown to inhibit insulin signaling and to induce insulin resistance (143). Enhanced exposure of skeletal muscle to high levels of fatty acids in circulation can result in enhanced levels of intramyocellular triglyceride storage. Because intramyocellular lipid droplets are stored in close vicinity to mitochondria, which constitute the main intracellular source of ROS, intramyocellular triglycerides are very vulnerable to oxidation. Upon peroxidation of intramyocellular triglycerides toxic lipid species are generated, including diacylglycerol (DAG), ceramide, and long-chain fatty acyl-CoA, which impair insulin signaling (143). Both enhanced influx, as a consequence of nutrient excess, and reduced efflux, as a result reduced oxidative capacity and mitochondrial dysfunction have been implicated in the accumulation of toxic intramyocellular lipids $(144,145)$. In support of a role of reduced efflux due to mitochondrial dysfunction, non-obese, insulin sensitive first degree relatives of patients with type 2 diabetes were shown to display impaired ability to switch to fat oxidation after high-fat intake (146), as well as higher levels of intramyocellular lipids and reduced oxidative capacity (147). These data implicate ROS and mitochondrial dysfunction in the development of insulin resistance.

It is unknown via which mechanisms insulin resistance is associated with a shortening of lifespan. If peripheral organs, such as skeletal muscle and adipose tissue become less responsive to insulin, euglycemia will be maintained by the capacity of the pancreas to hypersecrete insulin so as to overcome insulin resistance at peripheral organs. Exposure to continuous surges of hyperinsulinemia may overstimulate other tissues that have remained normally responsive to insulin, such as the liver, resulting in a pro-atherogenic lipid profile (148). Other data implicate adiponectin in the association between insulin resistance and lifespan. Adiponectin, an anti-inflammatory adipokine secreted by adipose tissue (149) was found to be negatively correlated with adipocyte size and obesity (150). Interestingly, elevated adiponectin levels have been observed in long-lived mice, such as the Ames dwarf mice (151) as well as in long-lived humans, such as centenarians (152-154). Recently, effects of adiponectin on peripheral insulin sensitivity also implicate central effects on reduction of high-fat diet-induced hypothalamic inflammation and insulin resistance (155).

\section{INFLAMMATION AND THE BRAIN INFLAMMATION AND AGING: INFLAMMAGING}

Inflammaging is characterized by the increase in chronic, lowgrade inflammation in the absence of overt infection that occurs with aging (156). Inflammaging as well as the circulatory markers that characterize this state, including C-reactive protein (CRP), interleukin-6 (IL-6), tumor necrosis factor $\alpha$ (TNF- $\alpha$ ), and interleukin 1 beta (IL1beta) are strong risk factors for many age-related diseases and mortality. It is thought that part of these circulatory factors are produced locally, after which these leak into the circulation. Different sources that contribute to the state of inflammaging include the accumulation of cellular debris and organelle components, accumulation of senescent cells, immunosenescence, changes in the gut microbiome and deregulation of the coagulation system.

Macromolecules, cells, and tissues are continuously damaged and repaired. Chronic inflammation is part of regular tissue remodeling as it facilitates tissue repair and turnover. However, a persistent inflammatory response can lead to tissue degeneration by activated leukocytes, cytokines, or collagen deposition. In literature, one key structure where links between inflammation and aging are emerging is the hypothalamus.

\section{HYPOTHALAMIC INFLAMMATION}

The hypothalamus is the seat of control of various metabolic and non-metabolic processes in the body, and is responsible for maintenance of homeostasis from early life through to aging. Besides its role in the synthesis and secretion of neurohormones, the hypothalamus regulates energy balance, stress responsiveness, as well as lipid and glucose metabolism. Diet-induced obesity has been shown to be associated with central leptin and insulin resistance (157). High-fat feeding has been shown to induce hypothalamic inflammation, which has been linked to the development of insulin resistance and obesity (157-159). In 2005, De Souza et al. demonstrated that 6 weeks of high-fat feeding induced impaired functional and molecular activation of the insulin-signaling pathway, with accompanying expression of several pro-inflammatory cytokines (IL-1 $\beta, \mathrm{TNF} \alpha$, and IL-6) and inflammatory responsive proteins in the hypothalamus (158). Moreover, hypothalamic inflammation was shown to decrease the efficacy of central insulin administration to inhibit lipolysis, even before the onset of peripheral insulin resistance in white adipose tissue (160). Recently, a series of experiments in mice has demonstrated that hypothalamic inflammation occurs rapidly after high-fat feeding and is mediated by hyper activation of hypothalamic microglia, which was associated with gliosis in the ARC nucleus and eventual reduction in the number of POMC neurons, which are key in the regulation of energy homeostasis and adiposity (161). 
Microglia are resident macrophages that play an important role in the clearance of cell debris via phagocytosis and the release of pro-inflammatory cytokines to recruit other immune responsive cells to the sites of injury in the CNS, including bloodborne macrophages. It is pivotal for tissue homeostasis and repair that the initial inflammatory immune response is followed by an active phase of resolution of inflammation and scar tissue. Recently, it has been shown that after insult, monocyte-derived M2-like macrophages are recruited to the site of injury and that these have an essential role as inflammation-resolving cells in recovery from acute CNS injury. The anti-inflammatory activity displayed by M2-like macrophages, notably their IL10 expression, is required for regulation of the activated microglia (162, 163). In addition, their expression of matrix degrading enzymes favors axonal regrowth by degradation of the glial scar (164). CNS specific T cells facilitate recruitment of blood-borne M2like macrophages to the CNS through the choroid plexus within the blood-CSF barrier (165). Age-related Th2 inflammation is associated with chronically elevated IL4 levels, which can disrupt choroid plexus barrier functions and thus prevent the resolution of pro-inflammatory processes and induce a state of CNS inflammaging.

\section{THERAPEUTIC MEASURES AND FUTURE PROSPECTS}

Since brain insulin has been linked with aging, two possible mechanisms can be proffered for enhancing brain insulin action (Figure 4). Enhanced insulin efficacy might occur through measures aimed at minimizing inflammation; and enhanced delivery might be promoted to the brain areas that are crucial for healthy longevity.

Inflammation, including that occurring in the hypothalamus, has been linked to age-related decline in insulin sensitivity. It has been shown that hypothalamic microglia hyperactivation is regulated by metabolic hormones [leptin, glucagon-like peptide 1 (GLP-1)] and diet but not by body weight per se (166). Inflammaging may be treatable and preventable through changes in lifestyle. Interventions that are currently applied to reduce the state of low-grade chronic inflammaging include low dosing of aspirin or statins, weight loss, and exercise. Notably, a lower intake of calories and food that is rich in saturated fat and carbohydrates has been shown to reduce inflammaging (167). In mice, it was shown that hypothalamic inflammation can be resolved by central administration of omega 3 and omega9 fatty acids after which body weight regulation and food intake were normalized (168). Physical exercise is known to be protective against numerous diseases and reduction of inflammation has been implicated in the health benefits conferred by exercise (169). Recently, in mice, exercise has also been shown to protect against hypothalamic inflammation induced by high-fat diet (170). Future research may focus on hypothalamic microglia as relevant targets for prevention and treatment of metabolic disorders.

The strong blood glucose lowering effects of intravenously administered insulin have hampered research on the role of insulin in the brain. These hypoglycemic effects can be circumvented by intranasal administration of insulin, which is an innovative way to enhance insulin concentration in the brain without affecting insulin concentration in the circulation (171). Intranasal administration of insulin was shown to be safe and effective in numerous studies in healthy humans and in patients with metabolic disease or cognitive impairment (172). Sub-chronic intranasal insulin application in humans was shown to decrease food intake and weight gain (92) in healthy young men, and to improve declarative memory and mood (173). Moreover, sub-chronic intranasal insulin application in humans was also shown to decrease HPA activation in response to a social stress test. It was shown that insulin may also influence meal-induced thermogenesis and postprandial insulin levels (174). Future research may focus on unraveling the effects of intranasal insulin on other aspects of energy and glucose metabolism in different age groups.

\section{CONCLUSION}

Insulin is the most powerful anabolic hormone discovered to date. Besides the well-established action of insulin in peripheral organs, such as liver, muscle, and adipose tissue, it is becoming

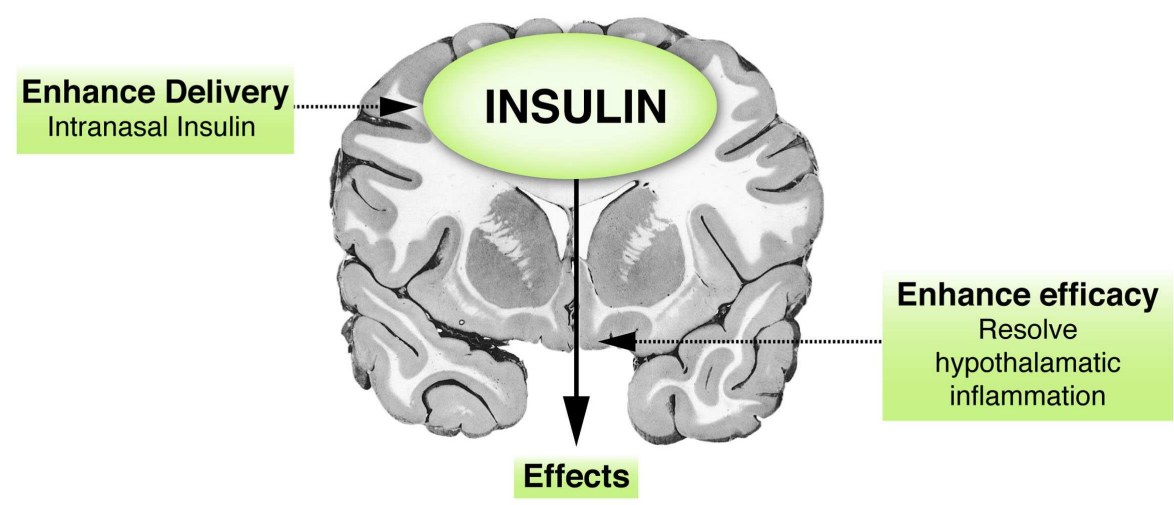

FIGURE 4 | Insulin and the brain: therapeutic implications.

Hypothetical figure presenting two possibilities of enhancing brain insulin action. First, a way of increasing insulin concentrations in the brain is via enhanced delivery, such as delivery via the intranasal route, which has been shown to have some beneficial effects. Second, insulin action could probably also be augmented by enhancing its efficacy, for example, via resolution of brain (hypothalamic) inflammation. 
increasingly clear that insulin affects important features of glucose metabolism via central mechanisms. Insulin signaling has been linked to longevity in organisms ranging from nematodes to mammals. While insulin is clearly a neuropeptide in nematodes, it is not yet clear how central insulin contributes to the differences in glucose metabolism that are observed in the context of conditions that are associated with accelerated aging, such as obesity, and delayed aging, such as healthy human longevity. However, novel data indicate that obesity is associated with reduced brain insulin action. Potential mechanisms that contribute to deficits in brain insulin action are impaired transport of insulin from the periphery to the brain and reduced brain insulin sensitivity due to hypothalamic inflammation. In contrast, we speculate that healthy longevity is associated with preserved brain insulin action, and discuss potential ways of enhancing brain insulin action in old age. Given the increasing prevalence of population aging, improving brain insulin action may represent an important therapeutic option to facilitate health in old age.

\section{ACKNOWLEDGMENTS}

The authors would like to thank Gerrit Kracht for his valuable contributions to the production of the figures contained in this review. This work was supported by the European Commission funded projects Switchbox (FP7, Health-F2-2010-2597772) and HUMAN (Health-2013-INNOVATION-1-602757).

\section{REFERENCES}

1. Holzenberger M, Dupont J, Ducos B, Leneuve P, Geloen A, Even PC, et al. IGF1 receptor regulates lifespan and resistance to oxidative stress in mice. Nature (2003) 421(6919):182-7. doi:10.1038/nature01298

2. Iser WB, Gami MS, Wolkow CA. Insulin signaling in Caenorhabditis elegans regulates both endocrine-like and cell-autonomous outputs. Dev Biol (2007) 303(2):434-47. doi:10.1016/j.ydbio.2006.04.467

3. Bartke A, Chandrashekar V, Dominici F, Turyn D, Kinney B, Steger R, et al. Insulin-like growth factor 1 (IGF-1) and aging: controversies and new insights. Biogerontology (2003) 4(1):1-8. doi:10.1023/A:1022448532248

4. Bluher M, Kahn BB, Kahn CR. Extended longevity in mice lacking the insulin receptor in adipose tissue. Science (2003) 299(5606):572-4. doi:10. $1126 /$ science. 1078223

5. Fulop T, Larbi A, Douziech N. Insulin receptor and ageing. Pathol Biol (2003) 51(10):574-80. doi:10.1016/j.patbio.2003.09.007

6. Fulop T Jr, Nagy JT, Worum I, Foris G, Mudri K, Varga P, et al. Glucose intolerance and insulin resistance with aging - studies on insulin receptors and post-receptor events. Arch Gerontol Geriatr (1987) 6(2):107-15. doi:10.1016/0167-4943(87)90003-3

7. Rozing MP, Westendorp RG, Frolich M, de Craen AJ, Beekman M, Heijmans BT, et al. Human insulin/IGF-1 and familial longevity at middle age. Aging (2009) 1(8):714-22.

8. Wijsman CA, Rozing MP, Streefland TC, le Cessie S, Mooijaart SP, Slagboom $\mathrm{PE}$, et al. Familial longevity is marked by enhanced insulin sensitivity. Aging Cell (2011) 10(1):114-21. doi:10.1111/j.1474-9726.2010.00650.x

9. Barbieri M, Gambardella A, Paolisso G, Varricchio M. Metabolic aspects of the extreme longevity. Exp Gerontol (2008) 43(2):74-8. doi:10.1016/j.exger.2007. 06.003

10. Barbieri M, Rizzo MR, Manzella D, Grella R, Ragno E, Carbonella M, et al. Glucose regulation and oxidative stress in healthy centenarians. Exp Gerontol (2003) 38(1-2):137-43. doi:10.1016/S0531-5565(02)00153-5

11. Paolisso G, Gambardella A, Ammendola S, D’Amore A, Balbi V, Varricchio M, et al. Glucose tolerance and insulin action in healthy centenarians. Am J Physiol (1996) 270(5 Pt 1):E890-4.

12. Duarte AI, Moreira PI, Oliveira CR. Insulin in central nervous system: more than just a peripheral hormone. J Aging Res (2012) 2012:384017. doi:10.1155/2012/384017
13. Schwartz MW, Seeley RJ, Tschop MH, Woods SC, Morton GJ, Myers MG, et al. Cooperation between brain and islet in glucose homeostasis and diabetes. Nature (2013) 503(7474):59-66. doi:10.1038/nature12709

14. Gerozissis K. Brain insulin: regulation, mechanisms of action and functions. Cell Mol Neurobiol (2003) 23(1):1-25. doi:10.1023/A:1025021529347

15. Derakhshan F, Toth C. Insulin and the brain. Curr Diabetes Rev (2013) 9(2):102-16. doi:10.2174/1573399811309020002

16. Anisimov VN. Insulin/IGF-1 signaling pathway driving aging and cancer as a target for pharmacological intervention. Exp Gerontol (2003) 38(10):1041-9. doi:10.1016/S0531-5565(03)00169-4

17. Wolkow CA, Kimura KD, Lee MS, Ruvkun G. Regulation of C. elegans life-span by insulinlike signaling in the nervous system. Science (2000) 290(5489):147-50. doi:10.1126/science.290.5489.147

18. Taguchi A, Wartschow LM, White MF. Brain IRS2 signaling coordinates life span and nutrient homeostasis. Science (2007) 317(5836):369-72. doi:10.1126/ science. 1142179

19. Houston DK, Nicklas BJ, Zizza CA. Weighty concerns: the growing prevalence of obesity among older adults. J Am Diet Assoc (2009) 109(11):1886-95. doi:10.1016/j.jada.2009.08.014

20. Mozumdar A, Liguori G. Persistent increase of prevalence of metabolic syndrome among U.S. adults: NHANES III to NHANES 1999-2006. Diabetes Care (2011) 34(1):216-9. doi:10.2337/dc10-0879

21. Centers for Disease Control and Prevention. National diabetes fact sheet: national estimates and general information on diabetes and prediabetes in the United States, 2011. Atlanta, GA: U.S. Department of Health and Human Services, Centers for Disease Control and Prevention (2011).

22. Alzheimer's Association. 2011 Alzheimer's disease facts and figures. Alzheimer Dement (2011) 7(2):208-44. doi:10.1016/j.jalz.2011.02.004

23. Schwartz MW, Porte D Jr. Diabetes, obesity, and the brain. Science (2005) 307(5708):375-9. doi:10.1126/science.1104344

24. Sherlock M, Toogood AA. Aging and the growth hormone/insulin like growth factor-I axis. Pituitary (2007) 10(2):189-203. doi:10.1007/s11102-007-0039-5

25. Frolich L, Blum-Degen D, Bernstein HG, Engelsberger S, Humrich J, Laufer $\mathrm{S}$, et al. Brain insulin and insulin receptors in aging and sporadic Alzheimer's disease. J Neural Transm (1998) 105(4-5):423-38. doi:10.1007/s007020050068

26. Zeyda M, Stulnig TM. Obesity, inflammation, and insulin resistance - a minireview. Gerontology (2009) 55(4):379-86. doi:10.1159/000212758

27. Haugaard N, Vaughan M, Haugaard ES, Stadie WC. Studies of radioactive injected labeled insulin. J Biol Chem (1954) 208(2):549-63.

28. Margolis RU, Altszuler N. Insulin in the cerebrospinal fluid. Nature (1967) 215(5108):1375-6. doi:10.1038/2151375a0

29. Havrankova J, Roth J, Brownstein M. Insulin receptors are widely distributed in the central nervous system of the rat. Nature (1978) 272(5656):827-9. doi: $10.1038 / 272827 \mathrm{a} 0$

30. Havrankova J, Schmechel D, Roth J, Brownstein M. Identification of insulin in rat brain. Proc Natl Acad Sci U S A (1978) 75(11):5737-41. doi:10.1073/pnas. 75.11 .5737

31. Dorn A, Rinne A, Bernstein HG, Hahn HJ, Ziegler M. Insulin and C-peptide in human brain neurons (insulin/C-peptide/brain peptides/ immunohistochemistry/radioimmunoassay). J Hirnforsch (1983) 24(5): 495-9.

32. Dorn A, Bernstein HG, Rinne A, Ziegler M, Hahn HJ, Ansorge S. Insulinand glucagon-like peptides in the brain. Anat Rec (1983) 207(1):69-77. doi:10.1002/ar.1092070108

33. Baskin DG, Woods SC, West DB, van Houten M, Posner BI, Dorsa DM, et al. Immunocytochemical detection of insulin in rat hypothalamus and its possible uptake from cerebrospinal fluid. Endocrinology (1983) 113(5):1818-25. doi:10.1210/endo-113-5-1818

34. Wallum BJ, Taborsky GJ Jr, Porte D Jr, Figlewicz DP, Jacobson L, Beard JC, et al. Cerebrospinal fluid insulin levels increase during intravenous insulin infusions in man. J Clin Endocrinol Metab (1987) 64(1):190-4. doi:10.1210/jcem64-1-190

35. Schechter R, Whitmire J, Holtzclaw L, George M, Harlow R, Devaskar SU. Developmental regulation of insulin in the mammalian central nervous system. Brain Res (1992) 582(1):27-37. doi:10.1016/0006-8993(92)90313-X

36. Hallschmid M, Schultes B. Central nervous insulin resistance: a promising target in the treatment of metabolic and cognitive disorders? Diabetologia (2009) 52(11):2264-9. doi:10.1007/s00125-009-1501-x 
37. Abraham MA, Filippi BM, Kang GM, Kim MS, Lam TK. Insulin action in the hypothalamus and dorsal vagal complex. Exp Physiol (2014) 99(9):1104-9. doi:10.1113/expphysiol.2014.079962

38. Frank HJ, Pardridge WM. A direct in vitro demonstration of insulin binding to isolated brain microvessels. Diabetes (1981) 30(9):757-61. doi:10.2337/diab. 30.9.757

39. Havrankova J, Roth J, Brownstein MJ. Concentrations of insulin and insulin receptors in the brain are independent of peripheral insulin levels. Studies of obese and streptozotocin-treated rodents. J Clin Invest (1979) 64(2):636-42. doi:10.1172/JCI109504

40. Schechter R, Beju D, Gaffney T, Schaefer F, Whetsell L. Preproinsulin I and II mRNAs and insulin electron microscopic immunoreaction are present within the rat fetal nervous system. Brain Res (1996) 736(1-2):16-27. doi:10.1016/ 0006-8993(96)00664-6

41. Banks WA, Kastin AJ. Differential permeability of the blood-brain barrier to two pancreatic peptides: insulin and amylin. Peptides (1998) 19(5):883-9. doi:10.1016/S0196-9781(98)00018-7

42. Devaskar SU, Holekamp N, Karycki L, Devaskar UP. Ontogenesis of the insulin receptor in the rabbit brain. Horm Res (1986) 24(4):319-27. doi:10.1159/ 000180573

43. Banks WA. The source of cerebral insulin. Eur J Pharmacol (2004) 490(13):5-12. doi:10.1016/j.ejphar.2004.02.040

44. Baura GD, Foster DM, Porte D Jr, Kahn SE, Bergman RN, Cobelli C, et al. Saturable transport of insulin from plasma into the central nervous system of dogs in vivo. A mechanism for regulated insulin delivery to the brain. J Clin Invest (1993) 92(4):1824-30. doi:10.1172/JCI116773

45. Duffy KR, Pardridge WM. Blood-brain barrier transcytosis of insulin in developing rabbits. Brain Res (1987) 420(1):32-8. doi:10.1016/0006-8993(87) 90236-8

46. Frank HJ, Jankovic-Vokes T, Pardridge WM, Morris WL. Enhanced insulin binding to blood-brain barrier in vivo and to brain microvessels in vitro in newborn rabbits. Diabetes (1985) 34(8):728-33. doi:10.2337/diab.34.8.728

47. Frank HJ, Pardridge WM. Insulin binding to brain microvessels. Adv Metab Disord (1983) 10:291-302. doi:10.1016/B978-0-12-027310-2.50016-5

48. Freude S, Plum L, Schnitker J, Leeser U, Udelhoven M, Krone W, et al. Peripheral hyperinsulinemia promotes tau phosphorylation in vivo. Diabetes (2005) 54(12):3343-8. doi:10.2337/diabetes.54.12.3343

49. Pardridge WM. Receptor-mediated peptide transport through the blood-brain barrier. Endocr Rev (1986) 7(3):314-30. doi:10.1210/edrv-7-3-314

50. Pardridge WM, Eisenberg J, Yang J. Human blood-brain barrier insulin receptor. J Neurochem (1985) 44(6):1771-8. doi:10.1111/j.1471-4159.1985. tb07167.x

51. Banks WA, Jaspan JB, Kastin AJ. Selective, physiological transport of insulin across the blood-brain barrier: novel demonstration by speciesspecific radioimmunoassays. Peptides (1997) 18(8):1257-62. doi:10.1016/ S0196-9781(97)00198-8

52. Porte D Jr, Seeley RJ, Woods SC, Baskin DG, Figlewicz DP, Schwartz MW. Obesity, diabetes and the central nervous system. Diabetologia (1998) 41(8):863-81. doi:10.1007/s001250051002

53. Sankar R, Thamotharan S, Shin D, Moley KH, Devaskar SU. Insulin-responsive glucose transporters-GLUT8 and GLUT4 are expressed in the developing mammalian brain. Brain Res Mol Brain Res (2002) 107(2):157-65. doi:10.1016/ S0169-328X(02)00487-4

54. Weindl A, Sofroniew MV. Relation of neuropeptides to mammalian circumventricular organs. Adv Biochem Psychopharmacol (1981) 28:303-20.

55. Pardridge WM. Transport of insulin-related peptides and glucose across the blood-brain barrier. Ann N Y Acad Sci (1993) 692:126-37. doi:10.1111/j.17496632.1993.tb26211.x

56. Blasberg RG, Patlak C, Fenstermacher JD. Intrathecal chemotherapy: brain tissue profiles after ventriculocisternal perfusion. J Pharmacol Exp Ther (1975) 195(1):73-83.

57. Burbach JP. Neuropeptides from concept to online database www. neuropeptides.nl. Eur J Pharmacol (2010) 626(1):27-48. doi:10.1016/j.ejphar. 2009.10.015

58. Clarke DW, Mudd L, Boyd FT Jr, Fields M, Raizada MK. Insulin is released from rat brain neuronal cells in culture. J Neurochem (1986) 47(3):831-6. doi:10.1111/j.1471-4159.1986.tb00686.x

59. Schechter R, Yanovitch T, Abboud M, Johnson G III, Gaskins J. Effects of brain endogenous insulin on neurofilament and MAPK in fetal rat neuron cell cultures. Brain Res (1998) 808(2):270-8. doi:10.1016/S0006-8993(98) 00842-7

60. Taniguchi CM, Emanuelli B, Kahn CR. Critical nodes in signalling pathways: insights into insulin action. Nat Rev Mol Cell Biol (2006) 7(2):85-96. doi: $10.1038 / \mathrm{nrm} 1837$

61. Eijkelenboom A, Burgering BM. FOXOs: signalling integrators for homeostasis maintenance. Nat Rev Mol Cell Biol (2013) 14(2):83-97. doi:10. 1038/nrm3507

62. Saltiel AR, Kahn CR. Insulin signalling and the regulation of glucose and lipid metabolism. Nature (2001) 414(6865):799-806. doi:10.1038/414799a

63. Heidenreich KA, Zahniser NR, Berhanu P, Brandenburg D, Olefsky JM. Structural differences between insulin receptors in the brain and peripheral target tissues. J Biol Chem (1983) 258(14):8527-30.

64. Boyd FT Jr, Raizada MK. Effects of insulin and tunicamycin on neuronal insulin receptors in culture. Am J Physiol (1983) 245(3):C283-7.

65. Zahniser NR, Goens MB, Hanaway PJ, Vinych JV. Characterization and regulation of insulin receptors in rat brain. J Neurochem (1984) 42(5):1354-62. doi:10.1111/j.1471-4159.1984.tb02795.x

66. van Houten M, Posner BI. Insulin binds to brain blood vessels in vivo. Nature (1979) 282(5739):623-5. doi:10.1038/282623a0

67. Raizada MK, Yang JW, Fellows RE. Binding of [125I] insulin to specific receptors and stimulation of nucleotide incorporation in cells cultured from rat brain Brain Res (1980) 200(2):389-400. doi:10.1016/0006-8993(80)90929-4

68. van Houten M, Posner BI, Kopriwa BM, Brawer JR. Insulin binding sites localized to nerve terminals in rat median eminence and arcuate nucleus. Science (1980) 207(4435):1081-3. doi:10.1126/science.6986652

69. Wickelgren I. Tracking insulin to the mind. Science (1998) 280(5363):517-9. doi:10.1126/science.280.5363.517

70. Zhao W, Chen H, Xu H, Moore E, Meiri N, Quon MJ, et al. Brain insulin receptors and spatial memory. Correlated changes in gene expression, tyrosine phosphorylation, and signaling molecules in the hippocampus of water maze trained rats. J Biol Chem (1999) 274(49):34893-902. doi:10.1074/jbc.274.49. 34893

71. Zhao WQ, Chen H, Quon MJ, Alkon DL. Insulin and the insulin receptor in experimental models of learning and memory. Eur J Pharmacol (2004) 490(13):71-81. doi:10.1016/j.ejphar.2004.02.045

72. de la Monte SM, Wands JR. Review of insulin and insulin-like growth factor expression, signaling, and malfunction in the central nervous system: relevance to Alzheimer's disease. J Alzheimer Dis (2005) 7(1):45-61.

73. Avogaro A, de Kreutzenberg SV, Fadini GP. Insulin signaling and life span. Pflugers Arch (2010) 459(2):301-14. doi:10.1007/s00424-009-0721-8

74. Plum L, Schubert M, Bruning JC. The role of insulin receptor signaling in the brain. Trends Endocrinol Metab (2005) 16(2):59-65. doi:10.1016/j.tem.2005. 01.008

75. Schulingkamp RJ, Pagano TC, Hung D, Raffa RB. Insulin receptors and insulin action in the brain: review and clinical implications. Neurosci Biobehav Rev (2000) 24(8):855-72. doi:10.1016/S0149-7634(00)00040-3

76. Dickson BJ. Development. Wiring the brain with insulin. Science (2003) 300(5618):440-1. doi:10.1126/science.1084513

77. Song J, Wu L, Chen Z, Kohanski RA, Pick L. Axons guided by insulin receptor in Drosophila visual system. Science (2003) 300(5618):502-5. doi:10.1126/ science. 1081203

78. Torres-Aleman I. Insulin-like growth factors as mediators of functional plasticity in the adult brain. Horm Metab Res (1999) 31(2-3):114-9. doi:10.1055/ s-2007-978707

79. Recio-Pinto E, Rechler MM, Ishii DN. Effects of insulin, insulin-like growth factor-II, and nerve growth factor on neurite formation and survival in cultured sympathetic and sensory neurons. J Neurosci (1986) 6(5):1211-9.

80. Puro DG, Agardh E. Insulin-mediated regulation of neuronal maturation. Science (1984) 225(4667):1170-2. doi:10.1126/science.6089343

81. Sugimoto K, Baba M, Suda T, Yasujima M, Yagihashi S. Peripheral neuropathy and microangiopathy in rats with insulinoma: association with chronic hyperinsulinemia. Diabetes Metab Res Rev (2003) 19(5):392-400. doi:10.1002/ dmrr.395

82. Kremerskothen J, Wendholt D, Teber I, Barnekow A. Insulin-induced expression of the activity-regulated cytoskeleton-associated gene (ARC) in human neuroblastoma cells requires p21(ras), mitogen-activated protein kinase/extracellular regulated kinase and src tyrosine kinases but is protein kinase C-independent. Neurosci Lett (2002) 321(3):153-6. 
83. Palovcik RA, Phillips MI, Kappy MS, Raizada MK. Insulin inhibits pyramidal neurons in hippocampal slices. Brain Res (1984) 309(1):187-91. doi:10.1016/ 0006-8993(84)91028-X

84. Barbaccia ML, Chuang DM, Costa E. Is insulin a neuromodulator? Adv Biochem Psychopharmacol (1982) 33:511-8.

85. Boyd FT Jr, Clarke DW, Muther TF, Raizada MK. Insulin receptors and insulin modulation of norepinephrine uptake in neuronal cultures from rat brain. $J$ Biol Chem (1985) 260(29):15880-4.

86. Baskin DG, Brewitt B, Davidson DA, Corp E, Paquette T, Figlewicz DP, et al. Quantitative autoradiographic evidence for insulin receptors in the choroid plexus of the rat brain. Diabetes (1986) 35(2):246-9. doi:10.2337/diab.35.2.246

87. Miller DW, Keller BT, Borchardt RT. Identification and distribution of insulin receptors on cultured bovine brain microvessel endothelial cells: possible function in insulin processing in the blood-brain barrier. J Cell Physiol (1994) 161(2):333-41. doi:10.1002/jcp.1041610218

88. Dudek H, Datta SR, Franke TF, Birnbaum MJ, Yao R, Cooper GM, et al. Regulation of neuronal survival by the serine-threonine protein kinase Akt. Science (1997) 275(5300):661-5. doi:10.1126/science.275.5300.661

89. Takadera T, Sakura N, Mohri T, Hashimoto T. Toxic effect of a beta-amyloid peptide (beta 22-35) on the hippocampal neuron and its prevention. Neurosci Lett (1993) 161(1):41-4. doi:10.1016/0304-3940(93)90135-8

90. Tanaka M, Sawada M, Yoshida S, Hanaoka F, Marunouchi T. Insulin prevents apoptosis of external granular layer neurons in rat cerebellar slice cultures. Neurosci Lett (1995) 199(1):37-40. doi:10.1016/0304-3940(95)12009-S

91. Kern W, Peters A, Fruehwald-Schultes B, Deininger E, Born J, Fehm HL Improving influence of insulin on cognitive functions in humans. Neuroendocrinology (2001) 74(4):270-80. doi:10.1159/000054694

92. Hallschmid M, Benedict C, Schultes B, Fehm HL, Born J, Kern W. Intranasal insulin reduces body fat in men but not in women. Diabetes (2004) 53(11):3024-9. doi:10.2337/diabetes.53.11.3024

93. Benedict C, Hallschmid M, Schultes B, Born J, Kern W. Intranasal insulin to improve memory function in humans. Neuroendocrinology (2007) 86(2):136-42. doi:10.1159/000106378

94. Woods SC, Lotter EC, McKay LD, Porte D Jr. Chronic intracerebroventricular infusion of insulin reduces food intake and body weight of baboons. Nature (1979) 282(5738):503-5. doi:10.1038/282503a0

95. Eikelis N, Esler M. The neurobiology of human obesity. Exp Physiol (2005) 90(5):673-82. doi:10.1113/expphysiol.2005.031385

96. Pocai A, Lam TK, Gutierrez-Juarez R, Obici S, Schwartz GJ, Bryan J, et al. Hypothalamic K(ATP) channels control hepatic glucose production. Nature (2005) 434(7036):1026-31. doi:10.1038/nature03439

97. Spanswick D, Smith MA, Mirshamsi S, Routh VH, Ashford ML. Insulin activates ATP-sensitive $\mathrm{K}+$ channels in hypothalamic neurons of lean, but not obese rats. Nat Neurosci (2000) 3(8):757-8. doi:10.1038/77660

98. Vidarsdottir S, Smeets PA, Eichelsheim DL, van Osch MJ, Viergever MA, Romijn JA, et al. Glucose ingestion fails to inhibit hypothalamic neuronal activity in patients with type 2 diabetes. Diabetes (2007) 56(10):2547-50. doi:10.2337/db07-0193

99. Schwartz MW, Sipols AJ, Marks JL, Sanacora G, White JD, Scheurink A, et al. Inhibition of hypothalamic neuropeptide $\mathrm{Y}$ gene expression by insulin. Endocrinology (1992) 130(6):3608-16. doi:10.1210/en.130.6.3608

100. Cotero VE, Routh VH. Insulin blunts the response of glucose-excited neurons in the ventrolateral-ventromedial hypothalamic nucleus to decreased glucose. Am J Physiol Endocrinol Metab (2009) 296(5):E1101-9. doi:10.1152/ajpendo. 90932.2008

101. Bruning JC, Gautam D, Burks DJ, Gillette J, Schubert M, Orban PC, et al. Role of brain insulin receptor in control of body weight and reproduction. Science (2000) 289(5487):2122-5. doi:10.1126/science.289.5487.2122

102. Obici S, Zhang BB, Karkanias G, Rossetti L. Hypothalamic insulin signaling is required for inhibition of glucose production. Nat Med (2002) 8(12):1376-82. doi:10.1038/nm1202-798

103. Kaiyala KJ, Prigeon RL, Kahn SE, Woods SC, Schwartz MW. Obesity induced by a high-fat diet is associated with reduced brain insulin transport in dogs. Diabetes (2000) 49(9):1525-33. doi:10.2337/diabetes.49.9.1525

104. Kenyon CJ. The genetics of ageing. Nature (2010) 464(7288):504-12. doi:10. 1038/nature08980

105. Braendle C, Milloz J, Felix MA. Mechanisms and evolution of environmental responses in Caenorhabditis elegans. Curr Top Dev Biol (2008) 80:171-207. doi:10.1016/S0070-2153(07)80005-6
106. Klass M, Hirsh D. Non-ageing developmental variant of Caenorhabditis elegans. Nature (1976) 260(5551):523-5. doi:10.1038/260523a0

107. Shore DE, Carr CE, Ruvkun G. Induction of cytoprotective pathways is central to the extension of lifespan conferred by multiple longevity pathways. PLoS Genet (2012) 8(7):e1002792. doi:10.1371/journal.pgen.1002792

108. Kimura KD, Tissenbaum HA, Liu Y, Ruvkun G. daf-2, an insulin receptor-like gene that regulates longevity and diapause in Caenorhabditis elegans. Science (1997) 277(5328):942-6. doi:10.1126/science.277.5328.942

109. Lin K, Dorman JB, Rodan A, Kenyon C. daf-16: an HNF-3/forkhead family member that can function to double the life-span of Caenorhabditis elegans. Science (1997) 278(5341):1319-22. doi:10.1126/science.278.5341.1319

110. Ogg S, Paradis S, Gottlieb S, Patterson GI, Lee L, Tissenbaum HA, et al. The Fork head transcription factor DAF-16 transduces insulin-like metabolic and longevity signals in C. elegans. Nature (1997) 389(6654):994-9. doi:10.1038/40194

111. Apfeld J, Kenyon C. Regulation of lifespan by sensory perception in Caenorhabditis elegans. Nature (1999) 402(6763):804-9. doi:10.1038/45544

112. Broughton SJ, Slack C, Alic N, Metaxakis A, Bass TM, Driege Y, et al. DILP-producing median neurosecretory cells in the Drosophila brain mediate the response of lifespan to nutrition. Aging Cell (2010) 9(3):336-46. doi:10.1111/j.1474-9726.2010.00558.x

113. van Heemst D. Insulin, IGF-1 and longevity. Aging Dis (2010) 1(2):147-57.

114. Brown-Borg HM, Borg KE, Meliska CJ, Bartke A. Dwarf mice and the ageing process. Nature (1996) 384(6604):33. doi:10.1038/384033a0

115. Flurkey K, Papaconstantinou J, Miller RA, Harrison DE. Lifespan extension and delayed immune and collagen aging in mutant mice with defects in growth hormone production. Proc Natl Acad Sci U S A (2001) 98(12):6736-41. doi:10.1073/pnas.111158898

116. Masternak MM, Panici JA, Bonkowski MS, Hughes LF, Bartke A. Insulin sensitivity as a key mediator of growth hormone actions on longevity. J Gerontol A Biol Sci Med Sci (2009) 64(5):516-21. doi:10.1093/gerona/glp024

117. Bartke A, Westbrook R. Metabolic characteristics of long-lived mice. Front Genet (2012) 3:288. doi:10.3389/fgene.2012.00288

118. Facchini FS, Hua N, Abbasi F, Reaven GM. Insulin resistance as a predictor of age-related diseases. J Clin Endocrinol Metab (2001) 86(8):3574-8. doi:10.1210/jcem.86.8.7763

119. Paolisso G, Scheen A, Lefebvre P. Glucose handling, diabetes and ageing. Horm Res (1995) 43(1-3):52-7. doi:10.1159/000184237

120. Bourey RE, Kohrt WM, Kirwan JP, Staten MA, King DS, Holloszy JO. Relationship between glucose tolerance and glucose-stimulated insulin response in 65-year-olds. J Gerontol (1993) 48(4):M122-7. doi:10.1093/geronj/48.4.M122

121. Elahi D, Muller DC, McAloon-Dyke M, Tobin JD, Andres R. The effect of age on insulin response and glucose utilization during four hyperglycemic plateaus. Exp Gerontol (1993) 28(4-5):393-409. doi:10.1016/0531-5565(93)90066-M

122. Pratley RE, Coon PJ, Muller DC, Rogus EM, Goldberg AP. The effects of single and sequential insulin infusions on glucose disposal in older men. Exp Gerontol (1993) 28(4-5):381-91. doi:10.1016/0531-5565(93)90065-L

123. Couet C, Delarue J, Constans T, Lamisse F. Age-related insulin resistance: a review. Horm Res (1992) 38(1-2):46-50. doi:10.1159/000182483

124. Fink RI, Kolterman OG, Griffin J, Olefsky JM. Mechanisms of insulin resistance in aging. J Clin Invest (1983) 71(6):1523-35. doi:10.1172/JCI110908

125. Rowe JW, Minaker KL, Pallotta JA, Flier JS. Characterization of the insulin resistance of aging. J Clin Invest (1983) 71(6):1581-7. doi:10.1172/JCI110914

126. Gumbiner B, Thorburn AW, Ditzler TM, Bulacan F, Henry RR. Role of impaired intracellular glucose metabolism in the insulin resistance of aging. Metabolism (1992) 41(10):1115-21. doi:10.1016/0026-0495(92)90296-M

127. Meneilly GS, Elahi D, Minaker KL, Sclater AL, Rowe JW. Impairment of noninsulin-mediated glucose disposal in the elderly. J Clin Endocrinol Metab (1989) 68(3):566-71. doi:10.1210/jcem-68-3-566

128. Paolisso G, Marrazzo G, de Riu S, Sgambato S, Varricchio M, d'Onofrio F, et al. Effects of mild-to-moderate hyperglycaemia per se on glucose production and uptake in the elderly. Eur J Med (1992) 1(1):6-12.

129. Schoenmaker M, de Craen AJ, de Meijer PH, Beekman M, Blauw GJ, Slagboom $\mathrm{PE}$, et al. Evidence of genetic enrichment for exceptional survival using a family approach: the Leiden longevity study. Eur J Hum Genet (2006) 14(1):79-84. doi:10.1038/sj.ejhg. 5201508

130. Rozing MP, Westendorp RG, de Craen AJ, Frolich M, de Goeij MC, Heijmans BT, et al. Favorable glucose tolerance and lower prevalence of metabolic syndrome in offspring without diabetes mellitus of nonagenarian siblings: the 
Leiden longevity study. J Am Geriatr Soc (2010) 58(3):564-9. doi:10.1111/j. 1532-5415.2010.02725.x

131. Westendorp RG, van Heemst D, Rozing MP, Frolich M, Mooijaart SP, Blauw GJ, et al. Nonagenarian siblings and their offspring display lower risk of mortality and morbidity than sporadic nonagenarians: the Leiden Longevity Study. J Am Geriatr Soc (2009) 57(9):1634-7. doi:10.1111/j.1532-5415.2009. 02381.x

132. Wijsman CA, van Opstal AM, Kan HE, Maier AB, Westendorp RG, Slagboom PE, et al. Proton magnetic resonance spectroscopy shows lower intramyocellular lipid accumulation in middle-aged subjects predisposed to familial longevity. Am J Physiol Endocrinol Metab (2012) 302(3):E344-8. doi:10.1152/ ajpendo.00455.2011

133. Dekker P, Maier AB, van Heemst D, de Koning-Treurniet C, Blom J, Dirks RW, et al. Stress-induced responses of human skin fibroblasts in vitro reflect human longevity. Aging Cell (2009) 8(5):595-603. doi:10.1111/j.1474-9726. 2009.00506.x

134. Heijmans BT, Beekman M, Houwing-Duistermaat JJ, Cobain MR, Powell J, Blauw GJ, et al. Lipoprotein particle profiles mark familial and sporadic human longevity. PLoS Med (2006) 3(12):e495. doi:10.1371/journal.pmed.0030495

135. Hu FB, Willett WC, Li T, Stampfer MJ, Colditz GA, Manson JE. Adiposity as compared with physical activity in predicting mortality among women. N Engl J Med (2004) 351(26):2694-703. doi:10.1056/NEJMoa042135

136. McLaughlin T, Abbasi F, Lamendola C, Reaven G. Heterogeneity in the prevalence of risk factors for cardiovascular disease and type 2 diabetes mellitus in obese individuals: effect of differences in insulin sensitivity. Arch Intern Med (2007) 167(7):642-8. doi:10.1001/archinte.167.7.642

137. McLaughlin T, Sherman A, Tsao P, Gonzalez O, Yee G, Lamendola C, et al. Enhanced proportion of small adipose cells in insulin-resistant vs insulinsensitive obese individuals implicates impaired adipogenesis. Diabetologia (2007) 50(8):1707-15. doi:10.1007/s00125-007-0708-y

138. Salans LB, Knittle JL, Hirsch J. The role of adipose cell size and adipose tissue insulin sensitivity in the carbohydrate intolerance of human obesity. J Clin Invest (1968) 47(1):153-65. doi:10.1172/JCI105705

139. Fontana L, Eagon JC, Trujillo ME, Scherer PE, Klein S. Visceral fat adipokine secretion is associated with systemic inflammation in obese humans. Diabetes (2007) 56(4):1010-3. doi:10.2337/db06-1656

140. Hotamisligil GS. Inflammation and metabolic disorders. Nature (2006) 444(7121):860-7. doi:10.1038/nature05485

141. Goldstein BJ, Mahadev K, Wu X. Redox paradox: insulin action is facilitated by insulin-stimulated reactive oxygen species with multiple potential signaling targets. Diabetes (2005) 54(2):311-21. doi:10.2337/diabetes.54.2.311

142. Papaconstantinou J. Insulin/IGF-1 and ROS signaling pathway cross-talk in aging and longevity determination. Mol Cell Endocrinol (2009) 299(1):89-100. doi:10.1016/j.mce.2008.11.025

143. Houstis N, Rosen ED, Lander ES. Reactive oxygen species have a causal role in multiple forms of insulin resistance. Nature (2006) 440(7086):944-8. doi:10.1038/nature04634

144. Samocha-Bonet D, Heilbronn LK, Lichtenberg D, Campbell LV. Does skeletal muscle oxidative stress initiate insulin resistance in genetically predisposed individuals? Trends Endocrinol Metab (2010) 21(2):83-8. doi:10.1016/j.tem. 2009.09.008

145. Moro C, Galgani JE, Luu L, Pasarica M, Mairal A, Bajpeyi S, et al. Influence of gender, obesity, and muscle lipase activity on intramyocellular lipids in sedentary individuals. J Clin Endocrinol Metab (2009) 94(9):3440-7. doi:10.1210/jc. 2009-0053

146. Heilbronn LK, Gregersen S, Shirkhedkar D, Hu D, Campbell LV. Impaired fat oxidation after a single high-fat meal in insulin-sensitive nondiabetic individuals with a family history of type 2 diabetes. Diabetes (2007) 56(8):2046-53. doi: $10.2337 / \mathrm{db} 06-1687$

147. Petersen KF, Dufour S, Befroy D, Garcia R, Shulman GI. Impaired mitochondrial activity in the insulin-resistant offspring of patients with type 2 diabetes. N Engl J Med (2004) 350(7):664-71. doi:10.1056/NEJMoa031314

148. Reaven GM. Compensatory hyperinsulinemia and the development of an atherogenic lipoprotein profile: the price paid to maintain glucose homeostasis in insulin-resistant individuals. Endocrinol Metab Clin North Am (2005) 34(1):49-62. doi:10.1016/j.ecl.2004.12.001

149. Combs TP, Berg AH, Obici S, Scherer PE, Rossetti L. Endogenous glucose production is inhibited by the adipose-derived protein Acrp30. JClin Invest (2001) 108(12):1875-81. doi:10.1172/JCI14120
150. Bahceci M, Gokalp D, Bahceci S, Tuzcu A, Atmaca S, Arikan S. The correlation between adiposity and adiponectin, tumor necrosis factor alpha, interleukin-6 and high sensitivity C-reactive protein levels. Is adipocyte size associated with inflammation in adults? J Endocrinol Invest (2007) 30(3):210-4. doi:10.1007/BF03347427

151. Wang Z, Al-Regaiey KA, Masternak MM, Bartke A. Adipocytokines and lipid levels in Ames dwarf and calorie-restricted mice. J Gerontol A Biol Sci Med Sci (2006) 61(4):323-31. doi:10.1093/gerona/61.4.323

152. Atzmon G, Pollin TI, Crandall J, Tanner K, Schechter CB, Scherer PE, et al. Adiponectin levels and genotype: a potential regulator of life span in humans. J Gerontol A Biol Sci Med Sci (2008) 63(5):447-53. doi:10.1093/ gerona/63.5.447

153. Bik W, Baranowska-Bik A, Wolinska-Witort E, Martynska L, Chmielowska M, Szybinska A, et al. The relationship between adiponectin levels and metabolic status in centenarian, early elderly, young and obese women. Neuro Endocrinol Lett (2006) 27(4):493-500.

154. Arai Y, Nakazawa S, Kojima T, Takayama M, Ebihara Y, Shimizu K-I, et al. High adiponectin concentration and its role for longevity in female centenarians. Geriatr Gerontol Int (2006) 6:32-9. doi:10.1111/j.1447-0594. 2006.00304.x

155. Koch CE, Lowe C, Legler K, Benzler J, Boucsein A, Bottiger G, et al. Central adiponectin acutely improves glucose tolerance in male mice. Endocrinology (2014) 155(5):1806-16. doi:10.1210/en.2013-1734

156. Franceschi C, Campisi J. Chronic inflammation (inflammaging) and its potential contribution to age-associated diseases. J Gerontol A Biol Sci Med Sci (2014) 69(Suppl 1):S4-9. doi:10.1093/gerona/glu057

157. Zhang X, Zhang G, Zhang H, Karin M, Bai H, Cai D. Hypothalamic IKKbeta/NF-kappaB and ER stress link overnutrition to energy imbalance and obesity. Cell (2008) 135(1):61-73. doi:10.1016/j.cell.2008.07.043

158. Cani PD, Amar J, Iglesias MA, Poggi M, Knauf C, Bastelica D, et al. Metabolic endotoxemia initiates obesity and insulin resistance. Diabetes (2007) 56(7):1761-72. doi:10.2337/db06-1491

159. Kleinridders A, Schenten D, Konner AC, Belgardt BF, Mauer J, Okamura T, et al. MyD88 signaling in the CNS is required for development of fatty acid-induced leptin resistance and diet-induced obesity. Cell Metab (2009) 10(4):249-59. doi:10.1016/j.cmet.2009.08.013

160. Scherer T, Lindtner C, Zielinski E, O’Hare J, Filatova N, Buettner C. Short term voluntary overfeeding disrupts brain insulin control of adipose tissue lipolysis. J Biol Chem (2012) 287(39):33061-9. doi:10.1074/jbc.M111.307348

161. Thaler JP, Yi CX, Schur EA, Guyenet SJ, Hwang BH, Dietrich MO, et al. Obesity is associated with hypothalamic injury in rodents and humans. J Clin Invest (2012) 122(1):153-62. doi:10.1172/JCI59660

162. Rapalino O, Lazarov-Spiegler O, Agranov E, Velan GJ, Yoles E, Fraidakis M, et al. Implantation of stimulated homologous macrophages results in partial recovery of paraplegic rats. Nat Med (1998) 4(7):814-21. doi:10.1038/ nm0798-814

163. Shechter R, London A, Varol C, Raposo C, Cusimano M, Yovel G, et al. Infiltrating blood-derived macrophages are vital cells playing an antiinflammatory role in recovery from spinal cord injury in mice. PLoS Med (2009) 6(7):e1000113. doi:10.1371/journal.pmed.1000113

164. Shechter R, Raposo C, London A, Sagi I, Schwartz M. The glial scar-monocyte interplay: a pivotal resolution phase in spinal cord repair. PLoS One (2011) 6(12):e27969. doi:10.1371/journal.pone.0027969

165. Kunis G, Baruch K, Rosenzweig N, Kertser A, Miller O, Berkutzki T, et al. IFNgamma-dependent activation of the brain's choroid plexus for CNS immune surveillance and repair. Brain (2013) 136(Pt 11):3427-40. doi:10.1093/brain/ awt259

166. Gao Y, Ottaway N, Schriever SC, Legutko B, Garcia-Caceres C, de la Fuente E, et al. Hormones and diet, but not body weight, control hypothalamic microglial activity. Glia (2014) 62(1):17-25. doi:10.1002/glia.22580

167. Fontana L. Neuroendocrine factors in the regulation of inflammation: excessive adiposity and calorie restriction. Exp Gerontol (2009) 44(1-2):41-5. doi:10.1016/j.exger.2008.04.005

168. Cintra DE, Ropelle ER, Moraes JC, Pauli JR, Morari J, Souza CT, et al. Unsaturated fatty acids revert diet-induced hypothalamic inflammation in obesity. PLoS One (2012) 7(1):e30571. doi:10.1371/journal.pone.0030571

169. Ford ES. Does exercise reduce inflammation? Physical activity and C-reactive protein among U.S. adults. Epidemiology (2002) 13(5):561-8. doi:10.1097/ 00001648-200209000-00012 
170. Yi CX, Al-Massadi O, Donelan E, Lehti M, Weber J, Ress C, et al. Exercise protects against high-fat diet-induced hypothalamic inflammation. Physiol Behav (2012) 106(4):485-90. doi:10.1016/j.physbeh.2012.03.021

171. Born J, Lange T, Kern W, McGregor GP, Bickel U, Fehm HL. Sniffing neuropeptides: a transnasal approach to the human brain. Nat Neurosci (2002) 5(6):514-6. doi:10.1038/nn0602-849

172. Benedict C, Dodt C, Hallschmid M, Lepiorz M, Fehm HL, Born J, et al. Immediate but not long-term intranasal administration of insulin raises blood pressure in human beings. Metabolism (2005) 54(10):1356-61. doi:10.1016/j.metabol. 2005.04.026

173. Benedict C, Hallschmid M, Hatke A, Schultes B, Fehm HL, Born J, et al. Intranasal insulin improves memory in humans. Psychoneuroendocrinology (2004) 29(10):1326-34. doi:10.1016/j.psyneuen.2004.04.003

174. Benedict C, Brede S, Schioth HB, Lehnert H, Schultes B, Born J, et al. Intranasal insulin enhances postprandial thermogenesis and lowers postprandial serum insulin levels in healthy men. Diabetes (2011) 60(1):114-8. doi:10.2337/db10-0329
Conflict of Interest Statement: The authors declare that the research was conducted in the absence of any commercial or financial relationships that could be construed as a potential conflict of interest.

Received: 13 November 2014; accepted: 21 January 2015; published online: 06 February 2015.

Citation: Akintola $A A$ and van Heemst D (2015) Insulin, aging, and the brain: mechanisms and implications. Front. Endocrinol. 6:13. doi: 10.3389/fendo.2015.00013 This article was submitted to Neuroendocrine Science, a section of the journal Frontiers in Endocrinology.

Copyright (C) 2015 Akintola and van Heemst. This is an open-access article distributed under the terms of the Creative Commons Attribution License (CC BY). The use, distribution or reproduction in other forums is permitted, provided the original author(s) or licensor are credited and that the original publication in this journal is cited, in accordance with accepted academic practice. No use, distribution or reproduction is permitted which does not comply with these terms. 